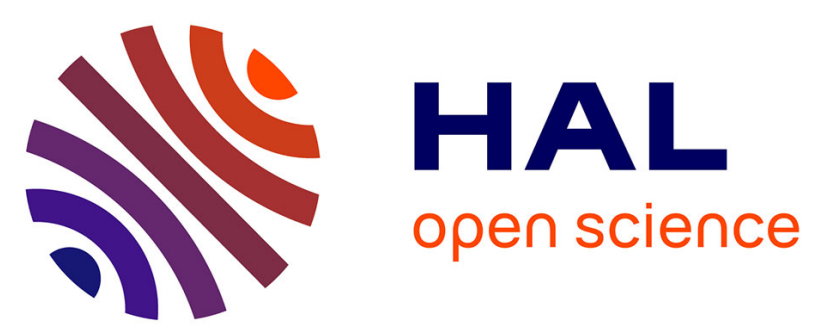

\title{
Demographic crash associated with high parasite load in an experimental roe deer (Capreolus capreolus) population
}

Marie-Line Maublanc, Eric Bideau, Denis Picot, Jean-Luc Rames, Michel Dubois, Hubert Ferté, Jean-François Gerard

\section{To cite this version:}

Marie-Line Maublanc, Eric Bideau, Denis Picot, Jean-Luc Rames, Michel Dubois, et al.. Demographic crash associated with high parasite load in an experimental roe deer (Capreolus capreolus) population. European Journal of Wildlife Research, 2009, 55 (6), pp.621-625. 10.1007/s10344-009-0298-8 . hal02913225

\section{HAL Id: hal-02913225 \\ https://hal.science/hal-02913225}

Submitted on 7 Aug 2020

HAL is a multi-disciplinary open access archive for the deposit and dissemination of scientific research documents, whether they are published or not. The documents may come from teaching and research institutions in France or abroad, or from public or private research centers.
L'archive ouverte pluridisciplinaire HAL, est destinée au dépôt et à la diffusion de documents scientifiques de niveau recherche, publiés ou non, émanant des établissements d'enseignement et de recherche français ou étrangers, des laboratoires publics ou privés. 


\title{
Demographic crash associated with high parasite load in an experimental roe deer (Capreolus capreolus) population
}

\author{
Marie-Line Maublanc1, Eric Bideau1, Denis Picot1, Jean-Luc Rames1, Michel Dubois2, Hubert Ferté 3, Jean- \\ François Gerard1
}

1 Comportement et Ecologie de la Faune Sauvage, Institut National de la Recherche Agronomique, P. O. Box 52627, 31326, Castanet-Tolosan Cedex, France

2 Inter Vivos, La Barberie, 50700, Urville, France

3 JE2533-USC Afssa "Vecpar", Université de Reims Champagne-Ardenne, UFR de Pharmacie, 51 rue Cognacq-Jay, 51096, Reims Cedex, France Received: 6 November 2008 / Revised: 4 June 2009 / Accepted: 22 June 2009

\begin{abstract}
In March 2002, ten roe deer (Capreolus capreolus) were released in a partly wooded 14.2-ha enclosure to investigate the effect of high population density on vegetation cover and demographic parameters. However, in mid 2003, five animals died after rapid emaciation. Two other deer were killed to carry out further post-mortem examination. In addition to a general loss of body mass, and injuries in males caused by the healthiest of them, we found a high level of parasitism. The remaining animals received anti-parasite treatment, and four other treated roe deer were added into the enclosure. All the deer were then captured and treated against parasites twice a year, the fawns being removed when first captured. Four years after the crash, the population seemed healthy: deaths no longer occurred; mean adult body mass reached $27.6 \mathrm{~kg}$ in March; females produced on average 1.6 fawns per year, with a mean body mass of $13.8 \mathrm{~kg}$ in October, and $16.7 \mathrm{~kg}$ in March. Furthermore, undergrowth cover changed little since March 2004. These results suggest that outbursts of parasites may cause population crashes in high-density situations before the onset of nutritive stress, and may explain certain cases of 'abnormal' (massive) mortality recorded in roe deer.
\end{abstract}

Key words Parasite outburst - mortality - body mass - food resources - social stress

\section{Introduction}

The roe deer (Capreolus capreolus) is currently abundant in Western Europe. Having almost become extinct in parts of southern Europe because of habitat loss and over-hunting in the first half of the last century, its numbers started increasing 20-40 years ago (Lovari et al. 2008), and are still increasing, as shown by the yearly numbers of animals hunted (Saint Andrieux and Pfaff 2007) and of collisions with cars (Mouron et al. 1998). High deer densities impacting on vegetation (Maizeret et al. 1989; Rooney and Dress 1997; Augustine and McNaughton 1998), population growth is expected to progressively decline because of food depletion. This assumption is supported by studies providing evidence for 'density-dependence' of some demographic parameters in several deer species (Mysterud et al. 2001; Solberg et al. 2001; Stewart et al. 2005). In high-density roe deer populations, the adult females' fecundity, and the fawns' body mass and survival are reduced (Vincent et al. 1995; Gaillard et al. 1996, 1997; Andersen and Linnell 1998), and the age at first breeding is delayed (Gaillard et al. 1992).

However, changes in population size are not always progressive, and roe deer populations are sometimes subjected to sudden, massive mortality, whose causes remain unclear (Lamarque et al. 1999).

We carried out an experiment to investigate the effect of high roe deer density on woodland vegetation and on the population's demographic parameters.

However, an unexpected population crash occurred $c a$. one year after the start of the experiment, leading us to search for its causes, and stop the trend. We report the results obtained in the present paper because they may shed light on the cases of massive mortality sometimes occurring in natural roe deer populations.

\section{Materials and Methods}

The study was conducted in a 14.2-ha enclosure in the INRA (National Agronomy Research Institute) experimental station of Gardouch, situated in South-West France ( $\left.43^{\circ} 22^{\prime} \mathrm{N} 1^{\circ} 40^{\prime} \mathrm{E}\right)$. It includes an 8.9-ha area of woodland, and two fallows of 3.9 and 1.4 ha, which were cut twice a year to allow observation from towers. The sylviculturally important and commonest tree in the woodland was the pubescent oak (Quercus pubescens). The other main trees and shrubs were the field maple (Acer campestre), wild service-tree (Sorbus torminalis), common hawthorn (Crataegus monogyna), blackthorn (Prunus spinosa), dog rose (Rosa canina), dogwood (Cornus sanguinea), and wayfaring tree 
(Viburnum lantana). The undergrowth consisted mainly of ivy (Hedera helix), brambles (Rubus sp.), privet (Ligustrum vulgare), knee holly (Ruscus aculeatus), and secondarily of wild madder (Rubia peregrina), spurge laurel (Daphne laureola), and honeysuckle (Lonicera periclymenum).

In March 2002, ten wild roe deer (five males, and five females, all two-four years old with the exception of a yearling female) were captured in the military area of ETBS (Establishment of Technical Experimentation) near Bourges (France) then released in the enclosure. However, dogs that entered the enclosure in autumn 2002 killed one of the males, and above all, a population crash occurred in mid 2003. Accordingly, the population was supplemented in November 2003 with four roe deer (two adult females originating from an enclosure of the Chizé reserve (France), and two male fawns born in small enclosures of our experimental station).

From March 2003, captures were carried out twice a year, in March and October, in order to weigh the deer using an electronic balance, and remove the young of the year from the enclosure. The young that escaped capture in October when 4-5 months old, were invariably captured the following March. After the population crash, all the deer of the enclosure received an anthelmintic treatment (ivomec- $\mathrm{D}^{\circledR}$ ) on each capture. On the population crash, we estimated the parasitic load, searching for external and internal parasites on dead animals: fresh faecal samples collected from dead animals or on the ground were examined by the MacMaster (Raynaud 1970) and the Baermann (Cabaret et al. 1980) methods, to estimate the number of eggs/larvae per gram. Gastrointestinal parasites were identified after egg incubation and larval growth. After the crash, we collected fresh faeces from every captured animal and estimated the parasite load (number of eggs/g).

Throughout the study, woodland vegetation was surveyed each year in February, using the Aldous method (Aldous 1944): cover and browsing intensity were assessed for each ligneous species $0-120 \mathrm{~cm}$ above ground in 36 circular plots of $40 \mathrm{~m}^{2}$ each, located at the nodes of a 50-m grid established on a map of the wood. We did not consider herbaceous species cover, which is too dependent on immediate weather conditions in February. Browsing intensity was only assessed to determine which species were regularly consumed by roe deer and which were not. In each plot, the cover of each species was estimated using five classes: absent (class 1), $\leq 5 \%$ (class 2), 6-20\% (class 3), $21-50 \%$ (class 4 ) and $>50 \%$ (class 5 ). We then used the median value of each class $(0,2.5,12.5,35$, and $75 \%$ ) to calculate cumulated cover for each plot, as the sum of individual species' cover. Three sets of plants were considered: (1) the 26 ligneous species present in the woodland, to provide an estimate of the overall cover; (2) the three species that were both consumed by roe deer and still leafed in late winter, i.e. brambles, ivy, and privet (referred to as 'food species'), to provide an index of food availability; (3) three species that were also leafed in late winter but not consumed by roe deer, i.e. knee holly, wild madder, and spurge laurel (referred to as 'non-food species'), to allow the evolutions of food and non-food species to be compared. Note that the cumulated cover ranged between 0 and a maximum value $=75 \% \mathrm{x}$ number of species taken into account. The yearly variations of cumulated cover were analysed using a linear mixed effect model with year as fixed-effect factor, and plot as random-effect factor. Analyses were made on log-transformed data in order to homogenise variance. The model was fitted in $\mathrm{R}$, using the lme function (R Development Core Team 2005). In the Results section, data are presented as untransformed means \pm SE.

\section{Results}

In spring 2002, i.e. two-three months after the population foundation, the four females more than one year old gave birth to $1.8 \pm 0.3$ fawns. In March 2003, the body mass of these young was $13.4 \pm 0.9 \mathrm{~kg}$. Compared to March 2002 , the body mass of the yearling female showed a $6.1-\mathrm{kg}$ increase, while that of the other females showed an increase of $1.4 \pm 0.4 \mathrm{~kg}$; the body mass of males was stable except for one, which lost $4.8 \mathrm{~kg}$ (Fig. 1).

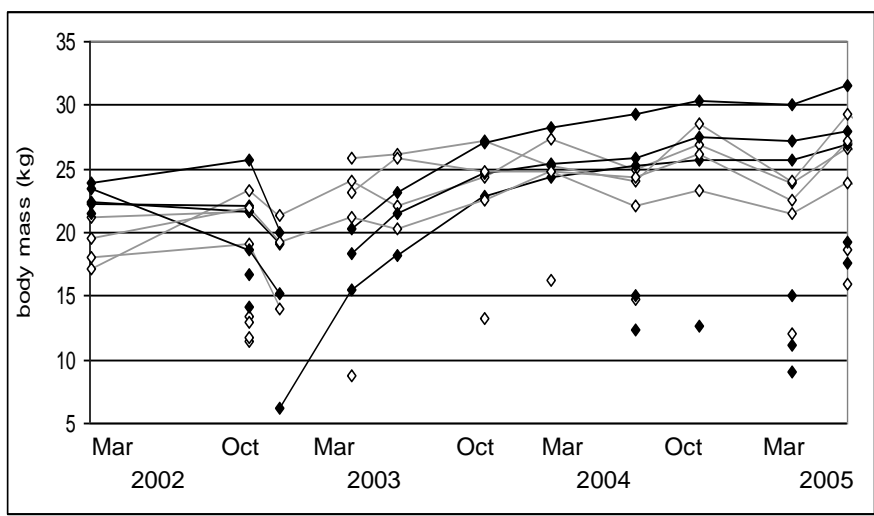

Fig. 1: Body mass of the enclosure's roe deer (dotted lines: the three animals that survived the crash, solid lines: other animals; black diamonds: males; white diamonds: females). Single points correspond to fawns native to the enclosure and removed on their first capture (in October or following March).

However, two females died after rapid emaciation in May and July 2003, and three males were found killed by the fourth male in May 2003. A third emaciated female and the remaining male were captured on mid-July and killed to carry out additional post-mortem examination. In addition to injuries in the three males found dead, we found a 
general loss of body mass (-3.6 $\pm 0.6 \mathrm{~kg}$ since March; Fig. 1), and a high level of parasitism. Animals showed tick (Ixodes ricinus) and louse infestation (mallophaga), associated with alopecia, and internal parasitism. We recorded many ostrid larvae (Cephenemya sp.) in the sinuses and the trachea $(\mathrm{n}=41.6 \pm 11.3)$, a mean of $550.0 \pm 118.4 \mathrm{eggs} / \mathrm{g}$ in the faeces, and identified gastrointestinal (Trichostrongylus sp., Spiculopteragia sp., Ostertagia sp., ChabertiaOesophagostomum sp. and Trichuris sp.), and lung parasites (Dictyocaulus sp.). On the other hand, the analyses did not reveal any pestivirus or paratuberculosis (Mycobacterium paratuberculosis).

The last two adult females (which had lost 2.0 and $2.8 \mathrm{~kg}$ since March, respectively) and a male fawn were caught in August 2003, and received the anthelmintic treatment in an attempt to reverse the disastrous trend. They all showed an increase in body mass when captured in autumn 2003 (Fig. 1). In contrast, a female fawn that was not caught in summer weighed only $8.6 \mathrm{~kg}$ in autumn. Killed for autopsy, she showed external and internal parasitism (700 eggs/g), was affected by a contagious ecthyma, a nephritis, and was dehydrated.

The four roe deer added into the enclosure in November 2003 raised the population to seven animals (four adult females, and three young males). Without any supplementary food but receiving the anthelmintic treatment twice a year, these seven individuals exhibited a relatively high body mass in March 2005, 2006 and 2007 (mean: $26.8 \pm 0.5$ kg; Fig. 1). All the females gave birth in 2005, 2006 and 2007, with an average of $1.6 \pm 0.2$ fawns per female; the body mass of young was $12.8 \pm 0.8 \mathrm{~kg}$ in October (2004 to 2007) and $16.7 \pm 1 \mathrm{~kg}$ in March (2005 to 2007). Parasitic charge remained almost null in adults $(7.8 \pm 3.4 \mathrm{eggs} / \mathrm{g})$, and acceptable in the young, never treated, animals when first captured $(138.5 \pm 33.1$ eggs/g).

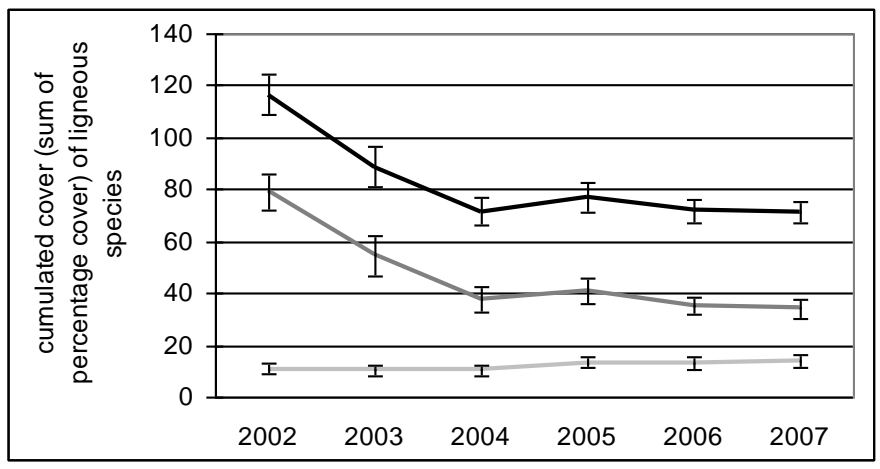

Fig. 2 Cumulative cover, between 0 and $120 \mathrm{~cm}$ above ground, of the 26 ligneous species of the woodland (black line), of the three main ligneous species leafed in late winter and consumed by roe deer (brambles, ivy and privet: dark grey line), and of three ligneous species leafed in late winter but not consumed (knee holly, spurge laurel and wild madder: light grey line). Bars are the SE for the 36 sampling plots used throughout the experiment.

Cover of under-storey vegetation declined between February 2002 and February 2004 (Fig. 2): in 2004, the cumulated cover of all the ligneous species was $61.4 \%$ that in 2002, while the cumulated cover of the three main food species was $47.8 \%$ that in 2002 . The decrease was significant for the 'food species' $\left(F_{1,71}=76.34 ; p<0.0001\right)$, and for all the ligneous species $\left(\mathrm{F}_{1,71}=74.09 ; \mathrm{p}<0.0001\right)$, since the main species consumed by roe deer were also the most abundant in the undergrowth. Within the same interval, the cover of the 'non-food species' did not vary $\left(\mathrm{F}_{1,71}=0.01\right.$; $\mathrm{p}=0.92$ ). From February 2004, the cover of the 'food species', and of all the ligneous species remained stable $\left(F_{1,107}=0.42 ; p=0.52\right.$, and $F_{1,107}=0.08 ; p=0.78$, respectively $)$, while that of the 'non-food species' increased slightly $\left(\mathrm{F}_{1,107}=10.46 ; \mathrm{p}<0.002\right)$.

\section{Discussion}

Population density in our enclosure (70.4 adults $/ \mathrm{km}^{2}$ at the start of the study, 49.3 from autumn 2003) was high in comparison with figures published for natural roe deer populations, where density estimates rarely exceed 30 deer / km² (Vincent et al. 1995; Gaillard et al. 1997; Kjellander et al. 2006, but see Gill et al. 1996). However, roe deer populations have high growth potential, and are mostly underestimated (Andersen and Linnell 2000).

In our high-density situation, browsing rapidly led to a decline in the under-storey vegetation, mainly depleting the abundance of food plants available in late winter. However, this trend stabilized from two years after the start of the study. On the other hand, one year after the deer introduction, five out of nine animals died after rapid emaciation. The final cause of death was harsh fights in males, but remained unclear in females. It is very unlikely that the deer became weak from starvation. All died or were dying between May and August, i.e. during the most productive period of the year. According to Aguirre et al. (1999), mortality due to starvation occurs during late winter and early spring. Moreover, no deer died or lost weight after September 2003, despite the ongoing decrease of food plant availability until late winter 2004. Actually, the body mass of roe deer remained high during successive winters, that of the young being $62.4 \%$ that of adults in March, which is considered as characteristic of highly productive populations (Gaillard et al. 1997).

The immediate stop of emaciation and mortality after anthelmintic treatment strongly supports the hypothesis of parasitic outburst as the final cause of death in females. This could be explained by the high roe deer population 
density: gastrointestinal nematodes are abundant in wild ruminants and their transmission rates depend on host population density (Drozdz and Dudzinski 1993; Arneberg 2001). Heavy infections may impair body condition (Zaffaroni et al. 1997), survival (Gulland 1992; Milner et al. 1999) or productivity (Fox 1997; Stien et al. 2002), reducing the immune reactivity of animals (Gasbarre (1997). Ectoparasites such as ticks or louses are also part of the normal fauna of mammals, and may impair body condition in high-density situations (De Bosschere et al. 2006). Furthermore, we suspect that the high-density situation acted as a source of chronic social stress, depleting immunoresistance and the physical condition of the animals, as shown to occur in many mammalian species (rats: Dhabhar and McEwen 1997; prairie voles: Sinclair and Lochmiller 2000; swine and cattle: Salak-Johnson and McGlone 2007; human beings: Segerstrom and Miller 2004).

In natural conditions with low hunting pressure, roe deer population densities may progressively increase and the impact on vegetation will become accentuated year by year. In these conditions, the number of fawns per adult female, juvenile body mass and consecutively adult body mass should decrease, this density dependence being more pronounced in low quality habitats (Pettorelli et al. 2002; Kjellander et al. 2006; Toïgo et al. 2006). Nevertheless, our results suggest that an often overlooked mortality factor related to high density could be outbursts of parasites or other diseases. Focardi et al. (2002) reported a population decline due to an enteropathogenic strain of Escherichia coli. In our study, the population crash occurred before the emergence of a food-limiting factor, probably because the high density was reached suddenly. High density led to (i) a rapid transfer of parasites between animals, and (ii) a high degree of social stress, which plausibly contributed to immunodepression.

These results shed some light on the problem of massive mortality found in several roe deer populations, sometimes before the emergence of a gap between the population density and the food availability in its habitat. Massive mortality preferentially affects high-density populations, and parasitic load seems higher in animals in the high-mortality context than in controls. It would be useful to carry out standardised faecal egg counts and autopsies in healthy populations and in populations showing 'abnormal' mortality, to calibrate a scale of infestation in relation to the body condition of the animals and to estimators of population density.

Acknowledgements We are grateful to the Midi-Pyrénées Region for financial support, as well as to the Establishment of technical experimentation at Bourges and to the Chizé reserve, which provided the roe deer. We are also grateful to Jean-Yves Jouglar and Pascal Versigny, from the National Veterinary College of Toulouse, who performed part of post-mortem examinations and of the egg counts. We thank Peter Winterton who checked the language of the manuscript. The authors declare that the experiments comply with the current laws of the country in which they were performed (France).

\section{References}

Aguirre A, Bröjer C, Mörner T (1999) Descriptive epidemiology of roe deer mortality in Sweden. J Wildl Diseases 35:753-762

Aldous S (1944) A deer browse method. J Mamm 25:130-136

Andersen R, Linnell J (1998) Ecological correlates of mortality of roe deer fawns in a predator-free environment. Can J Zool 76:1217-1225

Andersen R, Linnell J (2000) Irruptive potential in roe deer: density-dependent effects on body mass and fertility. J Wildl Manage 64:698-706

Arneberg P (2001) An ecological law and its macroecological consequences as revealed by studies of relationships between host densities and parasite prevalence. Ecography 24:352-358

Augustine D, McNaughton S (1998) Ungulate effects on the functional species composition of plant communities: herbivore selectivity and plant tolerance. J Wildl Manage 62:1165-1183

Cabaret J, Dakkak A, Bahaida B (1980) A technique for the evaluation of the number of lungworm first stage larvae in sheep faeces. Br Vet $\mathbf{J}$ 136:296-298

De Bosschere H, Casaer J, Neukermans A, Baert K, Ceulemans T, Tavernier P, Roels S (2006) Severe alopecia due to demodicosis in roe deer (Capreolus capreolus) in Belgium. Vet J 174:665-668

Dhabhar F, McEwen B (1997) Acute stress enhances while chronic stress suppresses cell-mediated immunity in vivo: a potential role for leukocyte trafficking. Brain, behavior and immunity 11:286-306

Drozdz J, Dudzinski W (1993) Changes in the intensity of infection of the roe deer, Capreolus capreolus (L.), with abomasum nematodes in relation to host density in a hunting ground. A Parasitologica 38:29-32

Focardi S, Raganella Pelliccioni E, Petrucco R, Toso S (2002) Spatial patterns and density dependence in the dynamics of a roe deer (Capreolus capreolus) population in central Italy. Oecologia 130:411-419

Fox M (1997) Pathophysiology of infection with gastrointestinal nematodes in domestic ruminants: recent developments. Vet Parasitology 72:285-308

Gaillard J-M, Sempere A, Boutin J-M, Van Laere G, Boisaubert B (1992) Effects of age and body weight on the proportion of females breeding in a population of roe deer (Capreolus capreolus). Can J Zool 70:1541-1545

Gaillard J-M, Delorme D, Boutin J-M, Van Laere G, Boisaubert B (1996) Body mass of roe deer fawns during winter in two contrasting populations. J Wildl Manage 60:29-36

Gaillard J-M, Boutin J-M, Delorme D, Van Laere G, Duncan P, Lebreton D (1997) Early survival in roe deer: causes and consequences of cohort variation in two contrasted populations. Ecologia 112:502-513

Gasbarre L (1997) Effects of gastrointestinal nematode infection on the ruminant immune system. Vet. Parasitology 72:327-343

Gill R, Johnson A, Francis A, Hiscocks K, Peace A (1996) Changes in roe deer (Capreolus capreolus L.) population density in response to forest habitat succession. Forest Ecol Manage 88:31-41

Gulland F (1992) The role of nematode parasites in Soay sheep (Ovis aries L.) mortality during a population crash. Parasitology 105:493-503 


\section{Accepted Manuscript - Eur J Wildl Res doi : 10.1007/s10344-009-0298-8}

Kjellander P, Gaillard J-M, Hewison M (2006) Density-dependent responses of fawn cohort body mass in two contrasting roe deer populations. Oecologia 146:521-530

Lamarque F, Barrat J, Hatier C, Artois M (1999) Causes of mortality in roe deer (Capreolus capreolus) diagnosed by an epidemiological surveillance network in France. Gibier faune sauvage 16:101-122

Lovari S, Herrero J, Conroy J, Maran T, Giannatos G, Stübbe M, Aulagnier S, Jdeidi T, Masseti M, Nader I, de Smet K \& Cuzin F (2008) Capreolus capreolus. In: 2008 IUCN Red List of Threatened Species. http://www.iucnredlist.org Accessed 18 May 2009

Maizeret C, Boutin J-M, Cibien C, Carlino J-P (1989) Effects of population density on the diet of roe deer and the availability of their food in the Chizé forest. A Theriol 34:235-246

Milner J, Elston D, Albon S (1999) Estimating the contributions of population density and climatic fluctuations to interannual variations in survival of Soay sheep. J Anim Ecol 68:1235-1247

Mouron D, Boisaubert B, Lamarque F, Sanaa M (1998) Recensement des collisions véhicules-grands mammifères sauvages. Evolution entre les inventaires de 1984-1986 et 1993-1994. In: Poc XXIII ${ }^{\text {rd }}$ Congr Int Union Game Biologists, Lyon, France, 1-6 Sept. Havet P, Taran E, Berthos J-C eds. Gibier Faune Sauvage, Game Wildl 15 (hors série / suppl., 3) pp 855-865

Mysterud A, Yoccoz N G, Stenseth N C, Langvatn R (2001) Effects of age, sex and density on body weight of Norwegian red deer: evidence of density dependent senescence. Proc R Soc Lond B Biol Sci 268:911-919

Pettorelli N, Gaillard J-M, Van Laere G, Duncan P, Kjellander P, Liberg O, Delorme D, Maillard D (2002) Variations in adult body mass in roe deer: the effects of population density at birth and of habitat quality. Proc R Soc Lond B Biol Sci 269:747-753

R Development Core Team (2005). R: A language and environment for statistical computing, reference index version 2.x.x. R Foundation for Statistical Computing, Vienna, Austria. ISBN 3-900051-07-0. http://www.R-project.org Accessed 27 Apr 2009

Raynaud J-P (1970) Etude de l'efficacité d'une technique de coproscopie quantitative pour le diagnostic de routine et le contrôle des infestations parasitaires de bovins, ovins, équins et porcins. Ann Parasitol Hum Comp 45 :321-342

Rooney T, Dress W (1997) Species loss over sixty-six years in the ground layer of Heart's Content, an old growth forest in Pennsylvania. Nat Areas J 17:297-305

Saint Andrieux C, Pfaff E (2007) Tableaux de chasse Cerf - Chevreuil - Sanglier. Saison 2005-2006. http://www.oncfs.gouv.fr/events/point_faune/mammifere/2007/FS276_TC_cerf_chevreuil_sanglier0506.pdf Accessed 27 Apr 2009

Salak-Johnson J, McGlone J (2007) Making sense of apparently conflicting data: stress and immunity in swine and cattle. J Anim Sci 85:E81E88

Segerstrom S, Miller G (2004) Psychological stress and the human immune system: a meta-analytic study of 30 years of inquiry. Psychol Bull 130:601-630

Sinclair J, Lochmiller R (2000) The winter immunoenhancement hypothesis: associations among immunity, density, and survival in prairie vole (Microtus ochrogaster) populations. Can J Zool 78:254-264

Solberg E, Jordhoy P, Strand O, Aanes R, Loison A, Saether B-E, Linnell J (2001) Effects of density-dependence and climate on the dynamics of a Svalbard reindeer population. Ecography 24:441-451

Stewart K, Bowyer T, Dick B, Johnson B, Kie J (2005) Density-dependent effects on physical condition and reproduction in North American elk: an experimental test. Oecologia 143:58-93

Stien A, Irvine R, Ropstad E, Halvorsen O, Langvatn R, Albon S (2002) The impact of gastrointestinal nematodes on wild reindeer: experimental and cross-sectional studies. J Anim Ecol 71:937-946

Toïgo C, Gaillard J-M, Van Laere G, Hewison M, Morellet N (2006) How does environmental variation influence body mass, body size and body condition? Roe deer as a case study. Ecography 29:301-308

Vincent J-P, Bideau E, Hewison M, Angibault J-M (1995) The influence of increasing density on body weight, kid production, home range and winter grouping in roe deer Capreolus capreolus. J Zool Lond 236:371-382

Zaffaroni E, Citterio C, Sala M, Lauzi S (1997) Impact of abomasal nematodes on roe deer and chamois body condition in an alpine environment. Parassitologia 39:313-317 